\title{
Article \\ Genital Brucella suis Biovar 2 Infection of Wild Boar (Sus scrofa) Hunted in Tuscany (Italy)
}

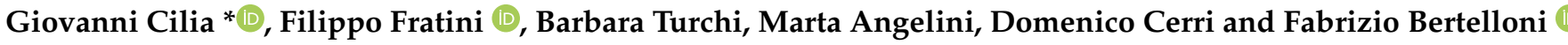 \\ Department of Veterinary Science, University of Pisa, Viale delle Piagge 2, 56124 Pisa, Italy; \\ filippo.fratini@unipi.it (F.F.); barbara.turchi@unipi.it (B.T.); marta94.ang@gmail.com (M.A.); \\ domenico.cerri@unipi.it (D.C.); fabrizio.bertelloni@unipi.it (F.B.) \\ * Correspondence: giovanni.cilia@vet.unipi.it
}

check for updates

Citation: Cilia, G.; Fratini, F.; Turchi, B.; Angelini, M.; Cerri, D.; Bertelloni, F. Genital Brucella suis Biovar 2

Infection of Wild Boar (Sus scrofa)

Hunted in Tuscany (Italy).

Microorganisms 2021, 9, 582. https:// doi.org/10.3390/microorganisms 903 0582

Academic Editor: Labrini

V. Athanasiou

Received: 23 February 2021

Accepted: 10 March 2021

Published: 12 March 2021

Publisher's Note: MDPI stays neutral with regard to jurisdictional claims in published maps and institutional affiliations.

Copyright: (C) 2021 by the authors. Licensee MDPI, Basel, Switzerland. This article is an open access article distributed under the terms and conditions of the Creative Commons Attribution (CC BY) license (https:/ / creativecommons.org/licenses/by/ $4.0 /)$.

\begin{abstract}
Brucellosis is a zoonosis caused by different Brucella species. Wild boar (Sus scrofa) could be infected by some species and represents an important reservoir, especially for B. suis biovar 2 . This study aimed to investigate the prevalence of Brucella spp. by serological and molecular assays in wild boar hunted in Tuscany (Italy) during two hunting seasons. From 287 animals, sera, lymph nodes, livers, spleens, and reproductive system organs were collected. Within sera, 16 (5.74\%) were positive to both rose bengal test (RBT) and complement fixation test (CFT), with titres ranging from 1:4 to 1:16 (corresponding to 20 and $80 \mathrm{ICFTU} / \mathrm{mL}$, respectively). Brucella spp. DNA was detected in four lymph nodes $(1.40 \%)$, five epididymides (1.74\%), and one fetus pool (2.22\%). All positive PCR samples belonged to Brucella suis biovar 2. The results of this investigation confirmed that wild boar represents a host for B. suis biovar. 2 and plays an important role in the epidemiology of brucellosis in central Italy. Additionally, epididymis localization confirms the possible venereal transmission.
\end{abstract}

Keywords: Brucella suis biovar 2; wild boar; surveillance; epidemiology; reproductive system

\section{Introduction}

Wild boar (Sus scrofa) is a large mammal that is globally spread, and it is able to colonize different habitats, including suburban and urban areas [1,2]. Wild boar has early puberty, from 5 to 10 months of age. They are characterized by high fertility and a gestation period from 115 to a maximum of 122 days [3-6]. Usually, the mating season is once a year, and males mate with more than one female [5-7]. Piglet births occur usually during the late winter and early spring, with a peak during February or March [7-9]. Furthermore, wild boar reproductive parameters are highly influenced by different features, such as habitat, climatic conditions, photoperiods, hunting pressure, and availability of food resources $[6,9,10]$. In recent years, in Europe, as well as in Italy, the population number constantly increased due to the high adaptability of these animals [1]. For some Italian regions, such as Tuscany, a high wild boar population density was estimated [11] considering the high number of hunted animals [11-14]. This aspect represents a serious problem for agriculture and public health $[15,16]$. As for the latter, wild boar could act as a reservoir for different bacterial pathogens, contributing to maintaining and disseminating some important infectious diseases and zoonosis, including brucellosis [17-23].

The genus Brucella includes 12 species: B. abortus, B. canis, B. ovis, B. suis, B. melitensis, B. neotomae, B. ceti, B. pinnipedialis, B. microti, B. inopinata, B. vulpis, and B. papionis. Among these, B. abortus, some biovars of B. suis, and, rarely, B. melitensis can infect swine, as well as wild boar [24,25]. Recently, B. microti was also isolated from the lymph node of a wild boar in the Czech Republic [26]. In Tuscany, as well as in many parts of Italy, bovine and ovine brucellosis was eradicated from several years [27]. As for B. suis, it was rarely reported in Europe, except for biovar 2, which is widely spread in East Europe and was recently isolated from domestic pigs and wild boar in Italy [28-30]. Wild boar represents one of the most important B. suis biovar 2 reservoirs. Furthermore, B. suis biovar 2 infection 
was recently reported in cows, in which seroconversion was detected without the presence of clinical signs [31,32]; human infections were rarely reported [33].

Brucellosis in swine caused by B. suis, especially biovar 2, is usually responsible for systemic infection and causes chronic diseases [24,34]. Bacteremia could persist for several months, and B. suis may persist in the uterus, causing chronic metritis [35,36]. Moreover, in males, genital infections seem to be frequent, with a tropism for epididymis. Brucellosis is responsible for reproductive disorders, characterized by abortion, stillbirths, decreased litter size, weak piglets, infertility, orchitis and epididymitis in males, and focal abscess formation $[34,35,37]$. The localization of $B$. suis in the epididymis could be due to a possible infection through venereal transmission [36].

This study aimed to assess Brucella spp. diffusion in wild boar hunted in the Tuscany region (Italy) to delineate the risk of spreading and possible transmission to animals and humans. For these purposes, serological and molecular assays were employed. Moreover, genital localization in male and female organs, including uterus, placenta and fetuses of pregnant animals, were analyzed to investigate the possibility of venereal and vertical transmissions.

\section{Materials and Methods}

\subsection{Sample Collection}

Over two consecutive hunting seasons (from November 2018 to January 2019 and from November 2019 to January 2020), serum and several organs were sampled from hunted wild boar. Blood samples were collected through an ocular puncture to obtain sera [38]. Moreover, from the same animals, mesenteric lymph nodes, spleen, liver, and reproductive system were collected. Regarding genital organs, testicles, epididymides, and uteri were sampled, as well as placentas and fetuses from pregnant wild boar. Organs (lungs, stomach, liver, and kidneys) obtained from all fetuses collected from the same pregnant animal were pooled and considered as a single sample. The sex and age class of each specimen were determined. The age class determination was performed by assessing the degree of tooth eruption and the wear and tear of teeth of the lower jaw, classifying three age groups: young (under 12 months), subadult (between 12 and 24 months), and adult (over 24 months) [39]. All animals were hunted in the Tuscany region during authorized hunting seasons, following the regional hunting law (Regolamento di attuazione della Legge Regionale 12 gennaio 1994, n. 3 D.P.G.R. 48/R/2017). Because sampling activities were performed in collaboration with hunter companies, the final number of samples was not predicted beforehand. No animals were sacrificed specifically for this study.

\subsection{Serological Investigations}

Within three hours, blood samples were transported in refrigerated conditions to the Laboratory of Infectious Diseases of the Department of Veterinary Science, University of Pisa (Italy), and obtained sera were stored at $-20{ }^{\circ} \mathrm{C}$ until analysis [38].

A rose bengal test (RBT) and complement fixation test (CFT) were employed to detect anti-brucella antibodies. RBT and CFT were performed as described by the World Organization for Animal Health (OIE) [40]; antigens used in both tests were obtained from the Istituto Zooprofilattico Sperimentale dell' Abruzzo e del Molise G. Caporale, Teramo. Considering the intrinsic limitation of the employed methods [40], only samples showing a positive reaction to both tests were considered as positive. As a positive and negative control, positive pig serum (provided by Istituto Zooprofilattico Sperimentale dell' Abruzzo e del Molise G. Caporale, Teramo) and sterilized saline water were employed, respectively.

\subsection{Molecular Investigations}

DNA was extracted from $25 \mu \mathrm{g}$ of each tissue sample (lymph node, spleen, liver, and reproductive organs) using the Quick-DNA Plus Kits (Zymo Research, Irvine, CA, USA), following the manufacturers' instructions. All the samples were tested by real-time PCR to identify the Brucella genus-specific target (bcsp31 gene) using a Rotorgene Corbett 6000 
(Corbett Research, Sidney, Australia) [41]. Subsequently, only Brucella-positive samples, were subjected to further real-time PCR assays to discriminate B. abortus, B. suis, B. melitentis, and B. ovis [42,43]. A total reaction volume of $15 \mu \mathrm{L}$ was prepared using $2 \times$ QuantiTect Probe PCR Master Mix (Qiagen, Hilden, Germany), $2 \mu \mathrm{M}$ of each primer, $500 \mathrm{nM}$ of each probe, and $3 \mu \mathrm{L}$ of DNA. Finally, another real-time PCR set was performed to identify the Brucella suis biovars [44]. The amplification of the target gene was performed using the HotStarTaq Master Mix Kit (Qiagen, Hilden, Germany) [44]. As a negative control, sterilized saline water was used. Amplicons were further sequenced (BMR Genomics, Padova, Italy) using the same amplification primer sets and analyzed using BioEdit Software [45]. Phylogenetic analysis was performed by the maximum likelihood method based on the Tamura-Nei model using MEGA 10 software [46].

\subsection{Statistical Analysis}

Data were analyzed with the chi-square $\left(X^{2}\right)$ test. The statistical test was used to evaluate serological- and molecular-positive rates in relation to sex (male or female), age class (young, subadult, or adult), province (Pisa, Lucca, Livorno, Grosseto or Siena), and hunting season (2018/2019 or 2019/2020). The statistical significance threshold was set at a $p$-value $\leq 0.05[47]$.

\section{Results}

Serum, lymph nodes, liver, spleen, and reproductive organs were collected from a total of 287 hunted wild boar: 118 males (86 and 32 from 2018/2019 and 2019/2020 hunting seasons, respectively) and 169 females (115 and 54 from 2018/2019 and 2019/2020 hunting seasons, respectively). Considering the sampling area, 200 wild boar were sampled during the 2018/2019 period: 75 from Grosseto province, 58 from Pisa province, 55 from Siena province, and 12 from Livorno province (Figure 1). In addition, 87 animals were investigated during the 2019/2020 period: 38,37 , and 12 wild boar were sampled from Pisa, Grosseto, and Lucca provinces, respectively (Figure 1).

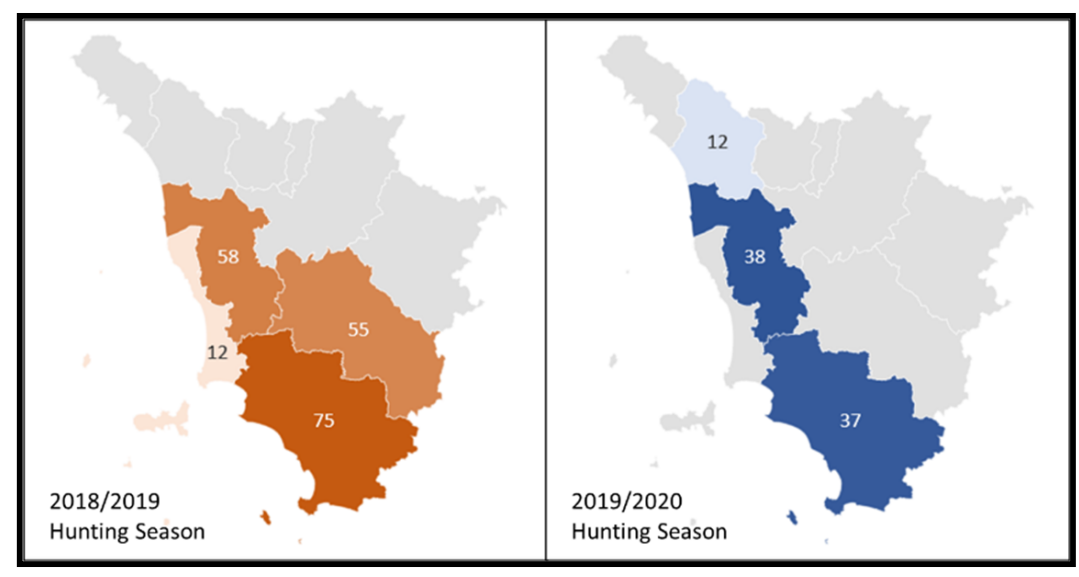

Figure 1. Geographical distribution of the sampling area included in the study (Tuscany region, Italy). The number of sampled hunted wild boar per province is indicated for hunting seasons (adapted by Cilia et al. [21]). In orange, hunting season 2018/2019; in blue, hunting season 2019/2020.

Moreover, 110 testicles and epididymides were collected from males (77 in 2018/2019 and 33 in 2019/2020); 37 uteri from females (36 in 2018/2019 and 1 in 2019/2020); and 45 uteri, placentae, and fetuses from pregnant females (34 in 2018/2019 and 11 in 2019/2020).

Results on the distribution of positive sera and organs for Brucella in relation to hunting season, province, sex, and age class are reported in Table 1 . In total, 26 wild boar specimens scored positive for Brucella spp. infection by serological or molecular analysis or both. 
Table 1. Distribution of positive sera and organs for pathogenic Brucella spp. in relation to hunting season, province, sex, and age class.

\begin{tabular}{|c|c|c|c|c|c|c|c|c|}
\hline $\begin{array}{c}\text { Hunting } \\
\text { Season }\end{array}$ & Province & Sex & Age Class & $\begin{array}{l}\text { Examined } \\
\text { Wild Boar }\end{array}$ & $\begin{array}{l}\text { Positive } \\
\text { Sera (\%) }\end{array}$ & $\begin{array}{c}\text { PCR-Positive } \\
\text { Lymph Nodes } \\
(\%)\end{array}$ & $\begin{array}{c}\text { PCR-Positive } \\
\text { Epididymides } \\
(\%)\end{array}$ & $\begin{array}{c}\text { PCR- } \\
\text { Positive } \\
\text { Fetuses (\%) }\end{array}$ \\
\hline \multirow{24}{*}{$\begin{array}{c}2018 / 2019 \\
(n=200)\end{array}$} & \multirow{6}{*}{$\begin{array}{c}\text { Pisa } \\
(n=58)\end{array}$} & Male & Adult & 9 & 0 & 0 & 0 & \\
\hline & & $(n=30)$ & Subadult & 10 & $3(30.0)$ & 0 & $2(20.0)$ & \\
\hline & & & Young & 11 & 0 & 0 & & \\
\hline & & Female & Adult & 14 & $1(7.14)$ & 0 & & 0 \\
\hline & & $(n=28)$ & Subadult & 5 & 0 & 0 & & 0 \\
\hline & & & Young & 9 & $2(22.2)$ & 1 (11.1) & & 0 \\
\hline & \multirow{6}{*}{$\begin{array}{c}\text { Grosseto } \\
(n=75)\end{array}$} & Male & Adult & 10 & 0 & 0 & $1(10.0)$ & \\
\hline & & $(n=29)$ & Subadult & 5 & 0 & $1(20.0)$ & 0 & \\
\hline & & & Young & 14 & 0 & 1 (7.14) & & \\
\hline & & Female & Adult & 22 & 0 & 0 & & 0 \\
\hline & & $(n=46)$ & Subadult & 5 & $1(20.0)$ & 0 & & 0 \\
\hline & & & Young & 19 & $1(5.26)$ & 0 & & 0 \\
\hline & \multirow{6}{*}{$\begin{array}{l}\text { Siena } \\
(n=55)\end{array}$} & Male & Adult & 10 & 0 & 0 & $1(10.0)$ & \\
\hline & & $(n=22)$ & Subadult & 4 & 0 & 0 & 0 & \\
\hline & & & Young & 8 & 0 & 0 & & \\
\hline & & Female & Adult & 21 & $1(4.76)$ & 0 & & 0 \\
\hline & & $(n=33)$ & Subadult & 2 & 0 & 0 & & 0 \\
\hline & & & Young & 10 & 0 & 0 & & 0 \\
\hline & \multirow{6}{*}{$\begin{array}{l}\text { Livorno } \\
(n=12)\end{array}$} & Male & Adult & 2 & 0 & $1(50.0)$ & 0 & \\
\hline & & $(n=4)$ & Subadult & 0 & 0 & 0 & 0 & \\
\hline & & & Young & 2 & $1(50.0)$ & 0 & 0 & \\
\hline & & Female & Adult & 4 & 0 & 0 & & 0 \\
\hline & & $(n=8)$ & Subadult & 0 & 0 & 0 & & 0 \\
\hline & & & Young & 4 & 0 & 0 & & 0 \\
\hline \multirow{18}{*}{$\begin{array}{c}2019 / 2020 \\
(n=87)\end{array}$} & \multirow{6}{*}{$\begin{array}{c}\text { Pisa } \\
(n=38)\end{array}$} & Male & Adult & 6 & $2(33.4)$ & 0 & 0 & \\
\hline & & $(n=13)$ & Subadult & 4 & 0 & 0 & 0 & \\
\hline & & & Young & 3 & 0 & 0 & 0 & \\
\hline & & Female & Adult & 21 & $1(4.76)$ & 0 & & $1(4.76)$ \\
\hline & & $(n=25)$ & Subadult & 1 & 0 & 0 & & 0 \\
\hline & & & Young & 3 & 0 & 0 & & 0 \\
\hline & \multirow{6}{*}{$\begin{array}{c}\text { Grosseto } \\
(n=37)\end{array}$} & Male & Adult & 11 & $1(9.10)$ & 0 & $1(9.10)$ & \\
\hline & & $(n=16)$ & Subadult & 1 & 0 & 0 & 0 & \\
\hline & & & Young & 4 & 0 & 0 & 0 & \\
\hline & & Female & Adult & 10 & $1(20.0)$ & 0 & & 0 \\
\hline & & $(n=21)$ & Subadult & 5 & 0 & 0 & & 0 \\
\hline & & & Young & 6 & 0 & 0 & & 0 \\
\hline & \multirow{6}{*}{$\begin{array}{l}\text { Lucca } \\
(n=12)\end{array}$} & Male & Adult & 1 & $1(100)$ & 0 & 0 & \\
\hline & & $(n=4)$ & Subadult & 0 & 0 & 0 & 0 & \\
\hline & & & Young & 3 & 0 & 0 & 0 & \\
\hline & & Female & Adult & 4 & 0 & 0 & & 0 \\
\hline & & $(n=8)$ & Subadult & 0 & 0 & 0 & & 0 \\
\hline & & & Young & 4 & 0 & 0 & & 0 \\
\hline
\end{tabular}

\subsection{Serological Investigations}

The results of this investigation showed that 16 out of 287 sera $(5.57 \%)$ scored positive for both serological assays. Titres ranging from 1:4 to 1:16 (corresponding to 20 and 80 international complement fixation test units per $\mathrm{ml}-\mathrm{ICFTU} / \mathrm{mL}$, respectively) were determined by CFT. In relation to hunting season, 11 out of $200(5.5 \%)$ and 6 out of $87(6.90 \%)$ scored positive in 2018/2019 and 2019/2020, respectively (Table 2). No statistical differences $(p>0.05)$ were detected for the serological positivity considering all parameters. Because Pisa and Grosseto are the only two provinces investigated during the two continuous hunting seasons, and comparing the same issues, no statistical differences $(p>0.05)$ were highlighted. 
Table 2. Brucella spp. positive wild boar specimens in relation to hunting seasons, province, sex, age, serological, and molecular investigations.

\begin{tabular}{|c|c|c|c|c|c|c|c|c|}
\hline \multirow{2}{*}{ Sample } & \multirow{2}{*}{ Hunting Season } & \multirow{2}{*}{ Province } & \multirow{2}{*}{ Sex } & \multirow{2}{*}{ Age } & \multicolumn{2}{|c|}{ Serological } & \multirow{2}{*}{ PCR PositiveTissue } & \multirow{2}{*}{ Sequencing } \\
\hline & & & & & RBT & $\mathrm{FdC}^{*}$ & & \\
\hline C14 & $2018 / 2019$ & PI & $\mathrm{M}$ & Subadult & + & $1: 4$ & None & / \\
\hline $\mathrm{C} 23$ & $2018 / 2019$ & LI & $\mathrm{M}$ & Young & + & $1: 4$ & None & / \\
\hline $\mathrm{C} 31$ & $2018 / 2019$ & PI & $\mathrm{M}$ & Adult & + & $1: 8$ & None & / \\
\hline $\mathrm{C} 33$ & $2018 / 2019$ & PI & $\mathrm{F}$ & Young & + & $1: 4$ & None & / \\
\hline $\mathrm{C} 34$ & $2018 / 2019$ & PI & M & Subadult & - & - & Epididymis & B. suis bv. 2 \\
\hline C63 & $2018 / 2019$ & SI & $\mathrm{M}$ & Adult & - & - & Epididymis & B. suis bv. 2 \\
\hline $\mathrm{C} 76$ & $2018 / 2019$ & PI & $\mathrm{F}$ & Young & - & - & Lymph nodes & B. suis bv. 2 \\
\hline $\mathrm{C} 82$ & $2018 / 2019$ & GR & $\mathrm{Fe}$ & Subadult & + & $1: 8$ & None & / \\
\hline C141 & $2018 / 2019$ & GR & $\mathrm{F}$ & Young & + & $1: 4$ & None & / \\
\hline C150 & $2018 / 2019$ & PI & M & Subadult & + & $1: 4$ & None & / \\
\hline C155 & $2018 / 2019$ & SI & $\mathrm{F}$ & Adult & + & $1: 16$ & None & / \\
\hline C171 & $2018 / 2019$ & GR & $\mathrm{M}$ & Adult & - & - & Epididymis & B. suis bv. 2 \\
\hline $\mathrm{C} 172$ & $2018 / 2019$ & PI & $\mathrm{M}$ & Subadult & + & $1: 8$ & None & / \\
\hline C175 & $2018 / 2019$ & PI & $\mathrm{M}$ & Young & + & $1: 4$ & None & - \\
\hline C186 & $2018 / 2019$ & PI & $\mathrm{M}$ & Subadult & - & - & Epididymis & B. suis bv. 2 \\
\hline C188 & $2018 / 2019$ & LI & $\mathrm{M}$ & Adult & - & - & Lymph nodes & B. suis bv. 2 \\
\hline C197 & $2018 / 2019$ & GR & $\mathrm{M}$ & Young & - & - & Lymph nodes & B. suis bv. 2 \\
\hline C200 & $2018 / 2019$ & GR & $\mathrm{M}$ & Subadult & - & - & Lymph nodes & B. suis bv. 2 \\
\hline C209 & $2019 / 2020$ & LU & $\mathrm{M}$ & Adult & + & $1: 16$ & None & / \\
\hline C218 & $2019 / 2020$ & GR & $\mathrm{M}$ & Adult & + & $1: 4$ & None & / \\
\hline C228 & $2019 / 2020$ & GR & $\mathrm{M}$ & Adult & - & - & Epididymis & B. suis bv. 2 \\
\hline $\mathrm{C} 242$ & $2019 / 2020$ & PI & $\mathrm{F}$ & Adult & + & $1: 4$ & None & / \\
\hline C251 & $2019 / 2020$ & GR & F & Adult & + & $1: 8$ & None & / \\
\hline C259 & $2019 / 2020$ & PI & $\mathrm{F}$ & Adult & - & - & Fetuses & B. suis bv. 2 \\
\hline C266 & $2019 / 2020$ & PI & $\mathrm{M}$ & Adult & + & $1: 4$ & None & / \\
\hline C267 & $2019 / 2020$ & PI & $\mathrm{M}$ & Adult & + & $1: 8$ & None & - \\
\hline
\end{tabular}

Legend: PI = Pisa, LI = Livorno, GR = Grosseto, SI = Siena, LU = Lucca; $\mathrm{M}=$ male, F = female; * 1:4 = $20 \mathrm{ICFTU} / \mathrm{mL} ; 1: 8=40 \mathrm{ICFTU} / \mathrm{mL}$; $1: 16=80 \mathrm{ICFTU} / \mathrm{mL}$

\subsection{Molecular Investigations}

Concerning molecular analysis, Brucella spp. DNA was detected in lymph nodes, epididymides, and fetuses, although no liver, spleen, testicle, uterus or placenta samples scored positive. Overall, 10 out of $287(3.48 \%)$ wild boar scored positive through real-time PCR. All of them scored negative in serological assays.

Specifically, 4 out of 287 (1.40\%) lymph nodes (all sampled in the 2018/2019 hunting season, $2.00 \%$ ) were positive (Table 2). In 5 epididymides (1.74\%), Brucella spp. DNA was found, 4 (2.00\%) and 1 (1.15\%) collected during the 2018/2019 and 2019/2020 hunting seasons, respectively (Table 2$)$. Moreover, only 1 fetus pool out of $45(2.22 \%)$ from an adult pregnant female hunted in 2019/2020 was positive. For lymph nodes, epididymides, and fetuses, no statistical differences $(p>0.05)$ were reported considering hunting seasons, provinces, and wild boar sex and age class, as well as when comparing Pisa and Grosseto during the two different hunting seasons.

All PCR-positive samples showed the presence of Brucella DNA belonging to Brucella suis. This was confirmed by phylogenetic analysis of sequences (Figure 2). Moreover, all Brucella suis belonged to biovar 2 . 


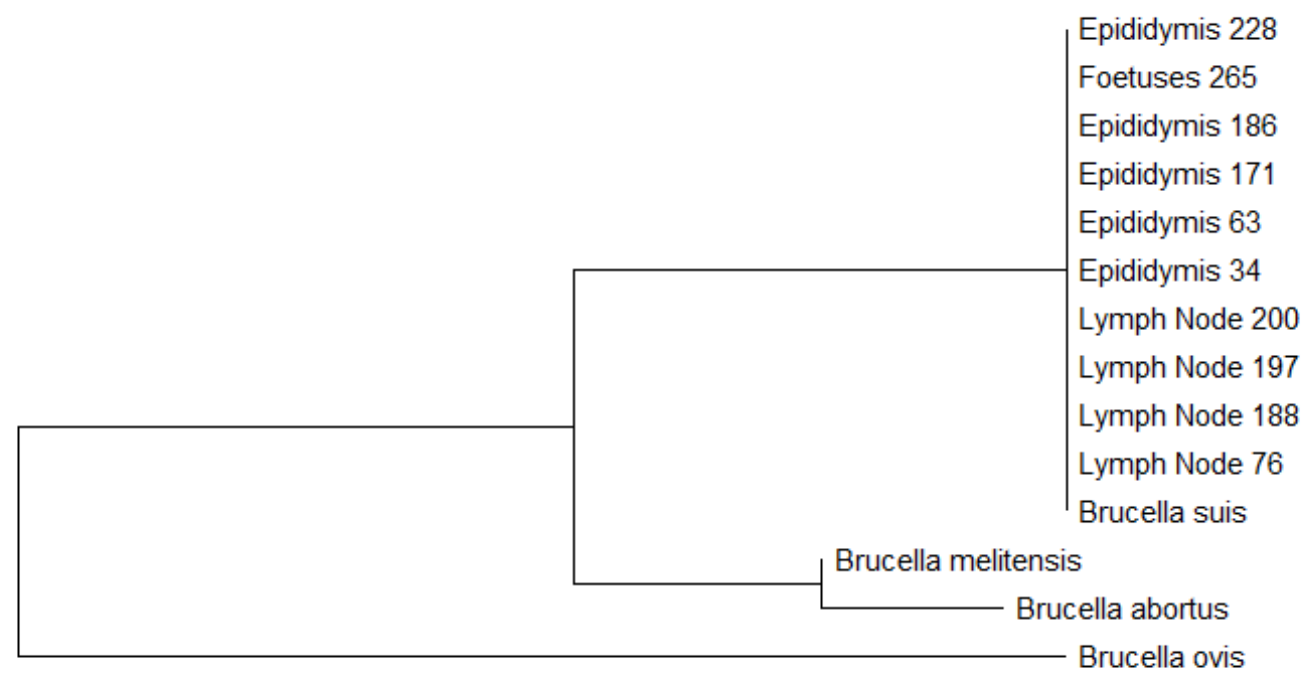

0.0050

Figure 2. Molecular phylogenetic analysis for 16s rRNA gene of positive lymph nodes and epididymides with Brucella suis, Brucella melitensis, Brucella abortus, and Brucella ovis by the maximum likelihood method based on the Tamura-Nei model. The branch lengths of the tree measured the number of substitutions per site. The analysis involved 14 nucleotide sequences. There was a total of 534 positions in the final dataset.

\section{Discussion}

The present investigation carried out on wild boar hunted in the Tuscany region (central Italy) reports seroprevalence for Brucella spp. and the identification of Brucella suis biovar 2 in lymph nodes, epididymides, and fetuses. Organs and sera were sampled during two consecutive hunting seasons (2018/2019 and 2019/2020), and no statistical differences were highlighted between wild boar sex, age class, provinces, and hunting seasons.

A previous study conducted from 1997 to 2000 in the same area did not report seropositivity to Brucella spp. in free-ranging wild boar [48], whereas, during the $2017 / 2018$ season, serological positivity was highlighted in $4.01 \%$ of specimens [14], which is consistent with results obtained in this investigation (5.75\% of seropositivity). These data suggest an increase in wild swine brucellosis in Tuscany over the last two decades. The percentages of positive wild boar sera and lymph nodes detected in this survey for Brucella spp. suggested a low infection rate of brucellosis among the wild boar population in Tuscany, as already demonstrated in other Italian regions [29,49-54] and Europe [23,55-60]. Traditional serological assays, RBT and CFT, do not allow the identification of Brucella species involved in the infection. However, because Tuscany and adjacent regions are currently free from bovine, ovine, and caprine brucellosis [27], and considering that in Central Italy, Brucella suis biovar 2 was recently isolated from wild boar [29] and pigs [28], it is possible to theorize that the detected serological positivity could be linked to an infection by the same biovar. Moreover, this hypothesis seems to be confirmed by Brucella suis biovar 2 identification in sampled organs by molecular methods.

Our results show no correlation between serological and molecular results. Few specific studies on wild boar were carried out regarding this issue, and most of them were performed on naturally infected animals. Regarding the real-time PCR protocol employed, it was reported to have great sensitivity for the pathogen. This assay can detect a low concentration of Brucella DNA, corresponding to $0.25 \mathrm{pg}$; assuming that $10-15 \mathrm{fg}$ of DNA is equivalent to 1 genome, 0.25 pg of DNA corresponds to about 16-25 genome copies [41,42]. On the other hand, RBT and CFT in swine are not free from false-positive reactions. Indeed, seronegativity of infected animals was previously reported by other authors and was attributed mainly to an intrinsic limit of the employed test and to the fact that serological 
tests are developed and standardized for domestic animals and not for feral swine [61]. In our case, some more aspects could be considered. Molecular analyses showed the presence of B. suis biovar 2 in lymph nodes of four seronegative animals; in particular, two of them were young, one was a subadult, and one an adult (animals older than about two years). In these animals, the occurrence of a possible congenital infection could be supposed. This condition is well described for bovine where "latent", "symptomless", or "chronic" serologically negative carriers are well described [62]. The detection of B. suis biovar 2 DNA in one fetus pool highlights the possibility of vertical transmission in this animal species. Five wild boar scored positive at the epididymis level only, without serological reactions. This could be linked to more sensitivity of molecular tests compared to serological tests, as suggested and shown by other authors [63]. Furthermore, there is the possibility of a restricted localization in the epididymis, causing low stimulation of the immune system and, consequently, no detectable antibodies. This could be the consequence of venereal transmission of the disease linked to a sexual transmission cycle among the wild boar population. This hypothesis could be supported by the fact that in these animals, Brucella DNA was detected only in the genital tract and not in lymph nodes. Finally, all serologically positive animals were PCR-negative, which could appear unusual. However, some authors have reported the impossibility of detecting Brucella in wild or domestic animals scored positive for serological examination, in some cases, even during experimental infections [64-66]. Furthermore, the negative results of PCR examinations on all livers and spleens could suggest chronic infection, a condition probably characterized by the presence of antibodies, at low titer in many cases, and associated with a low number of non-detectable bacteria in "latency" organs.

Brucellosis is characterized by genital tropism, causing orchitis, epididymitis, and infertility in males and abortion and sterility in females [67-69]. Moreover, Brucella suis has been demonstrated to be able to infect the reproductive system, especially in males [24,70]. In this investigation, B. suis biovar 2 has been detected in wild boar epididymides and fetuses. To the best of the authors' knowledge, this is the first evidence of Brucella suis biovar 2-specific localization in the epididymis of wild boar. Indeed, the obtained results show that the epididymis, and not testicles, seems to be the target organ of localization for $B$. suis biovar 2 in this animal species. This finding is consistent with the localization of other Brucella species, for example, B. ovis in rams [71]. The tropisms of Brucella spp. for epididymides and fetuses, instead of other genital organs, is related to the abundant presence of erythritol and fructose in these organs [72-74]. Fructose serves as the primary source of energy for the bacteria [75], and the high concentration of erythritol in fetal fluid, epididymis, and semen is strongly associated with genital brucellosis [76-78]. To the best of the authors' knowledge, no data are available in the literature about the exact localization of $B$. suis biovar 2 in the male reproductive tract of wild boar. Many studies investigated the presence of $B$. suis biovar 2 in the asymptomatic boar genital tract without specifying the exact organ, or sometimes reporting negative detection in testicles [50,56]. No macroscopic lesions were detected in any male genital organs collected during this survey. Epididymis localization in presumptive asymptomatic animals could induce a constant release of Brucella through the semen and consequently during coitus. The last hypothesis paves the way for new, interesting epidemiological considerations linked to wild boar reproductive behavior. Adult males are solitary animals living alone and searching for female groups during the reproductive season, sometimes crossing long distances, driving away other young or subadult sexually mature males and adult contenders, and eventually copulating with as many receptive sows as possible [5-7]. In this way, positive males could contribute to the spreading of $B$. suis biovar 2 by venereal transmission. The roaming of adult or subadult males, especially during reproductive seasons, could contribute to the diffusion of the disease. Indeed, regarding the Tuscany region, Brucella infection was previously reported in wild boar and pigs only in the south of the region $[14,29,51,79,80]$, whereas the present data suggest a diffusion of the disease in all investigated provinces without statistical differences. 


\section{Conclusions}

This investigation evaluated the presence of Brucella in wild boar through serological and molecular assays. As expected, due to brucellosis eradication in central Italy and species-specific association, Brucella suis resulted in being the only detected species.

The obtained data show the presence of Brucella suis biovar 2 in wild boar lymph nodes and, for the first time, in epididymides and fetuses. Because it is a neglected or underestimated issue, the impact and epidemiological role of Brucella suis infection on the reproductive system and, consequently, in reproductive performances of wild boar could be of interest. The monitoring seems to be of great importance because the infection could also be silent or chronic, increasing the possibility of spreading of disease among wild boar populations. Moreover, the infection in the reproductive system of wild boar could represent a serious hazard for swine, especially when semi-extensive breeding is adopted, as in several central Italy areas where breeding between domestic and wild swine is common. Further investigations should be performed to understand the prevalence of Brucella suis in the reproductive system and fetuses and the possible implication of venereal and vertical transmission among the wild boar population. Furthermore, other wild or domestic animals, such as hares, sharing the same environment should be included in a more complete monitoring program.

Author Contributions: Conceptualization, G.C., F.F. and F.B.; data curation, B.T.; formal analysis, G.C., B.T. and F.B.; funding acquisition, F.F.; investigation, G.C., M.A. and F.B.; supervision, F.F. and D.C.; writing - original draft, G.C., B.T. and F.B.; writing-review and editing, G.C., F.F., B.T., M.A., D.C. and F.B. All authors have read and agreed to the published version of the manuscript.

Funding: This research was funded by University of Pisa, grant number PRA_2018_56.

Institutional Review Board Statement: Not applicable.

Informed Consent Statement: Not applicable.

Data Availability Statement: The data presented in this study are available in the article.

Acknowledgments: We thank Fabrizio de Massis and his team at the National Reference Centre for Brucellosis (Istituto Zooprofilattico Sperimentale dell' Abruzzo e del Molise G. Caporale, Teramo, Italy) for providing the anti-Brucella antigens employed in this investigation.

Conflicts of Interest: The authors declare no conflict of interest.

\section{References}

1. Massei, G.; Kindberg, J.; Licoppe, A.; Gačić, D.; Šprem, N.; Kamler, J.; Baubet, E.; Hohmann, U.; Monaco, A.; Ozolinš, J.; et al. Wild boar populations up, numbers of hunters down? A review of trends and implications for Europe. Pest Manag. Sci. 2015, 71, 492-500. [CrossRef]

2. Castillo-Contreras, R.; Carvalho, J.; Serrano, E.; Mentaberre, G.; Fernández-Aguilar, X.; Colom, A.; González-Crespo, C.; Lavín, S.; López-Olvera, J.R. Urban wild boars prefer fragmented areas with food resources near natural corridors. Sci. Total Environ. 2018, 615, 282-288. [CrossRef]

3. Fonseca, C.; da Silva, A.A.; Alves, J.; Vingada, J.; Soares, A.M.V.M. Reproductive performance of wild boar females in Portugal. Eur. J. Wildl. Res. 2011, 57, 363-371. [CrossRef]

4. Bywater, K.A.; Apolonnio, M.; Cappai, N.; Sthephens, P.A. Litter size and latitude in a large mammal: The wild boar Sus scrofa. Mamm. Rev. 2010, 212-220. [CrossRef]

5. Henry, V.H. Length of Estrous Cycle and Gestation in European Wild Hogs. J. Wildl. Manage. 1968, 32, 406-408. [CrossRef]

6. Canu, A.; Scandura, M.; Merli, E.; Chirichella, R.; Bottero, E.; Chianucci, F.; Cutini, A.; Apollonio, M. Reproductive phenology and conception synchrony in a natural wild boar population. Hystrix 2015, 26, 1-8.

7. Poteaux, C.; Baubet, E.; Kaminski, G.; Brandt, S.; Dobson, F.S.; Baudoin, C. Socio-genetic structure and mating system of a wild boar population. J. Zool. 2009, 278, 116-125. [CrossRef]

8. Fernández-Llario, P.; Carranza, J. Reproductive performance of the wild boar in a mediterranean ecosystem under drought conditions. Ethol. Ecol. Evol. 2000, 12, 335-343. [CrossRef]

9. Malmsten, A.; Jansson, G.; Lundeheim, N.; Dalin, A.-M. The reproductive pattern and potential of free ranging female wild boars (Sus scrofa) in Sweden. Acta Vet. Scand. 2017, 59, 52. [CrossRef] [PubMed]

10. Šprem, N.; Piria, M.; Florijancic, T.; Antunovic, B.; Dumic, T.; Gutzmirtl, H.; Treer, T.; Curik, I. Morphometrical Analysis of Reproduction Traits for the Wild Boar (Sus scrofa L.) in Croatia. Agric. Conspec. Sci. 2011, 76, 263-265. 
11. Pittiglio, C.; Khomenko, S.; Beltran-Alcrudo, D. Wild boar mapping using population-density statistics: From polygons to high resolution raster maps. PLoS ONE 2018, 13, e0193295. [CrossRef]

12. Carnevali, L.; Pedrotti, L.; Riga, F.; Toso, S. Banca Dati Ungulati: Status, distribuzione, consistenza, gestione e prelievo venatorio delle popolazioni di Ungulati in Italia. Rapporto 2001-2005. Biol. Conserv. Della Fauna 2009, 117, 1-168.

13. Cilia, G.; Bertelloni, F.; Mignone, W.; Spina, S.; Berio, E.; Razzuoli, E.; Vencia, W.; Franco, V.; Cecchi, F.; Bogi, S.; et al. Molecular detection of Leptospira spp. in wild boar (Sus scrofa) hunted in Liguria region (Italy). Comp. Immunol. Microbiol. Infect. Dis. 2020, 68, 101410. [CrossRef]

14. Bertelloni, F.; Mazzei, M.; Cilia, G.; Forzan, M.; Felicioli, A.; Sagona, S.; Bandecchi, P.; Turchi, B.; Cerri, D.; Fratini, F. Serological survey on bacterial and viral pathogens in wild boars hunted in tuscany. Ecohealth 2020, 17, 85-93. [CrossRef] [PubMed]

15. Lombardini, M.; Meriggi, A.; Fozzi, A. Factors influencing wild boar damage to agricultural crops in Sardinia (Italy). Curr. Zool. 2017, 63, 507-514. [CrossRef]

16. Meng, X.J.; Lindsay, D.S.; Sriranganathan, N. Wild boars as sources for infectious diseases in livestock and humans. Philos. Trans. R. Soc. Lond. B. Biol. Sci. 2009, 364, 2697-2707. [CrossRef]

17. Bertelloni, F.; Cilia, G.; Bogi, S.; Ebani, V.V.; Turini, L.; Nuvoloni, R.; Cerri, D.; Fratini, F.; Turchi, B. Pathotypes and antimicrobial susceptibility of Escherichia coli isolated from wild boar (Sus scrofa) in Tuscany. Animals 2020, 10, 744. [CrossRef]

18. Pacini, M.I.; Forzan, M.; Cilia, G.; Bernardini, L.; Marzoli, F.; Pedonese, F.; Bandecchi, P.; Fratini, F.; Mazzei, M. Detection of pseudorabies virus in wild boar foetus. Animals 2020, 10, 366. [CrossRef]

19. Vengust, G.; Valencak, Z.; Bidovec, A. Presence of antibodies against Aujeszky's disease virus in wild boar (Sus scrofa) in Slovenia. J. Wildl. Dis. 2005, 41, 800-802. [CrossRef]

20. Mazzei, M.; Nardini, R.; Verin, R.; Forzan, M.; Poli, A.; Tolari, F. Serologic and molecular survey for hepatitis E virus in wild boar (Sus scrofa) in Central Italy. New Microbes New Infect. 2015, 7, 41-47. [CrossRef]

21. Cilia, G.; Bertelloni, F.; Angelini, M.; Cerri, D.; Fratini, F. Leptospira Survey in Wild Boar (Sus scrofa) Hunted in Tuscany, Central Italy. Pathogens 2020, 9, 377. [CrossRef]

22. Bertelloni, F.; Cilia, G.; Turchi, B.; Pinzauti, P.; Cerri, D.; Fratini, F. Epidemiology of leptospirosis in North-Central Italy: Fifteen years of serological data (2002-2016). Comp. Immunol. Microbiol. Infect. Dis. 2019, 65, 14-22. [CrossRef]

23. Grégoire, F.; Mousset, B.; Hanrez, D.; Michaux, C.; Walravens, K.; Linden, A. A serological and bacteriological survey of brucellosis in wild boar (Sus scrofa) in Belgium. BMC Vet. Res. 2012, 8, 1-8. [CrossRef]

24. Díaz Aparicio, E. Epidemiology of brucellosis in domestic animals caused by Brucella melitensis, Brucella suis and Brucella abortus. Rev. Sci. Tech. 2013, 32, 43-51, 53-60. [CrossRef] [PubMed]

25. Olsen, S.C.; Garin-Bastuji, B.; Blasco, J.M.; Nicola, A.M.; Samartino, L. Brucellosis. In Diseases of Swine; Zimmerman, J.J., Karriker, L.A., Ramirez, A., Schwartz, K.J., Stevenson, G.W., Eds.; Wiley-Blackwell: Hoboken, NJ, USA, 2012; pp. $697-708$.

26. Rónai, Z.; Kreizinger, Z.; Dán, Á.; Drees, K.; Foster, J.T.; Bányai, K.; Marton, S.; Szeredi, L.; Jánosi, S.; Gyuranecz, M. First isolation and characterization of Brucella microti from wild boar. BMC Vet. Res. 2015, 11, 147. [CrossRef]

27. EFSA (European Food Safety Authority); ECDC (European Centre for Disease Prevention and Control). The European Union One Health 2019 Zoonoses Report. EFSA J. 2021, 19. [CrossRef]

28. Barlozzari, G.; Franco, A.; Macrì, G.; Lorenzetti, S.; Maggiori, F.; Dottarelli, S.; Maurelli, M.; Di Giannatale, E.; Tittarelli, M.; Battisti, A.; et al. First report of Brucella suis biovar 2 in a semi free-range pig farm, Italy. Vet. Ital. 2015, 51, 151-154.

29. De Massis, F.; Di Provvido, A.; Di Sabatino, D.; Di Francesco, D.; Zilli, K.; Ancora, M.; Tittarelli, M. Isolation of Brucella suis biovar 2 from a wild boar in the Abruzzo Region of Italy. Vet. Ital. 2012, 48, 397-404.

30. Olsen, S.C.; Tatum, F.M. Swine brucellosis: Current perspectives. Vet. Med. (Auckland, N.Z.) 2017, 8, 1-12. [CrossRef] [PubMed]

31. Szulowski, K.; Iwaniak, W.; Weiner, M.; Złotnicka, J. Brucella suis biovar 2 isolations from cattle in Poland. Ann. Agric. Environ. Med. 2013, 20, 672-675.

32. Fretin, D.; Mori, M.; Czaplicki, G.; Quinet, C.; Maquet, B.; Godfroid, J.; Saegerman, C. Unexpected Brucella suis biovar 2 Infection in a dairy cow, Belgium. Emerg. Infect. Dis. 2013, 19, 2053-2054. [CrossRef]

33. Pappas, G. The changing Brucella ecology: Novel reservoirs, new threats. Int. J. Antimicrob. Agents 2010, 36, S8-S11. [CrossRef]

34. Poester, F.P.; Samartino, L.E.; Santos, R.L. Pathogenesis and pathobiology of brucellosis in livestock. Rev. Sci. Tech. 2013, 32, 105-115. [CrossRef] [PubMed]

35. Megid, J.; Antonio Mathias, L.; Robles, C.A. Clinical manifestations of brucellosis in domestic animals and humans. Open Vet. Sci. J. 2010, 4, 119-126. [CrossRef]

36. Alton, G.G. Brucella suis. In Animal Brucellosis; Nielsen, K., Duncan, R., Eds.; CRC Press: Boca Raton, FL, USA, 1990; pp. 411-422.

37. Meirelles-Bartoli, R.B.; Mathias, L.A.; Samartino, L.E. Brucellosis due to Brucella suis in a swine herd associated with a human clinical case in the State of São Paulo, Brazil. Trop. Anim. Health Prod. 2012, 44, 1575-1579. [CrossRef]

38. Arenas-Montes, A.; García-Bocanegra, I.; Paniagua, J.; Franco, J.J.; Miró, F.; Fernández-Morente, M.; Carbonero, A.; Arenas, A. Blood sampling by puncture in the cavernous sinus from hunted wild boar. Eur. J. Wildl. Res. 2013, 59, 299-303. [CrossRef]

39. Sáez-Royuela, C.; Gomariz, R.P.; Luis Tellería, J. Age determination of european wild boar. Wildl. Soc. Bull. 1989, 17, 326-329.

40. OIE (World Organization for Animal Health). Manual of Diagnostic Tests and Vaccines for Terrestrial Animals 2017, Chapter 2.1.4., (Brucella abortus, B. melitensis and B. suis) (Infection with B. abortus, B. melitensis and B. suis); OIE (World Organization for Animal Health): Paris, France, 2016; p. 44. 
41. dos Santos, L.S.; Sá, J.C.; dos Santos Ribeiro, D.L.; Chaves, N.P.; da Silva Mol, J.P.; Santos, R.L.; da Paixão, T.A.; de Carvalho Neta, A.V. Detection of Brucella sp. infection through serological, microbiological, and molecular methods applied to buffaloes in Maranhão State, Brazil. Trop. Anim. Health Prod. 2017, 49, 675-679. [CrossRef]

42. Redkar, R.; Rose, S.; Bricker, B.; DelVecchio, V. Real-time detection of Brucella abortus, Brucella melitensis and Brucella suis. Mol. Cell. Probes 2001, 15, 43-52. [CrossRef]

43. Moustacas, V.S.; Silva, T.M.A.; Costa, A.; Costa, L.F.; Paixão, T.A.; Santos, R.L. Real-time PCR for detection of Brucella ovis and Histophilus somni in ovine urine and semen. Arq. Bras. Med. Vet. Zootec. 2015, 67, 1751-1755. [CrossRef]

44. Fretin, D.; Whatmore, A.M.; Al Dahouk, S.; Neubauer, H.; Garin-Bastuji, B.; Albert, D.; Van Hessche, M.; Ménart, M.; Godfroid, J.; Walravens, K.; et al. Brucella suis identification and biovar typing by real-time PCR. Vet. Microbiol. 2008, 131, 376-385. [CrossRef]

45. Hall, T.A. BioEdit: A user-friendly biological sequence alignment editor and analysis program for Windows $95 / 98 / \mathrm{NT}$. Nucleic Acids Symp. Ser. 1999, 41, 95-98.

46. Kumar, S.; Stecher, G.; Li, M.; Knyaz, C.; Tamura, K. MEGA X: Molecular evolutionary genetics analysis across computing platforms. Mol. Biol. Evol. 2018, 35, 1547-1549. [CrossRef]

47. R Core Team R: A Language and Environment for Statistical Computing; R Found. Stat. Comput: Vienna Austria, 2015.

48. Ebani, V.V.; Cerri, D.; Poli, A.; Andreani, E. Prevalence of Leptospira and Brucella antibodies in wild boars (Sus scrofa) in Tuscany, Italy. J. Wildl. Dis. 2003, 39, 718-722. [CrossRef]

49. Pilo, C.; Addis, G.; Deidda, M.; Tedde, M.T.; Liciardi, M. A serosurvey for brucellosis in wild boar (Sus scrofa) in Sardinia, Italy. J. Wildl. Dis. 2015, 51, 885-888. [CrossRef] [PubMed]

50. Pilo, C.; Tedde, M.T.; Orrù, G.; Addis, G.; Liciardi, M. Brucella suis infection in domestic pigs in Sardinia (Italy). Epidemiol. Infect. 2015, 143, 2170-2177. [CrossRef]

51. Di Sabatino, D.; Garofolo, G.; Di Provvido, A.; Zilli, K.; Foschi, G.; Di Giannatale, E.; Ciuffetelli, M.; De Massis, F. Brucella suis biovar 2 multi locus sequence type ST16 in wild boars (Sus scrofa) from Abruzzi region, Italy. Introduction from Central-Eastern Europe? Infect. Genet. Evol. 2017, 55, 63-67. [CrossRef]

52. Gennero, M.S.; Grattarola, C.; Zoppi, S.; Di Giannatale, E.; Dondo, A. Brucellosisi in wild boars in Piedmont region. Épidémiologie Santé Anim. 2004, 45, 77-79.

53. Montagnaro, S.; Sasso, S.; De Martino, L.; Longo, M.; Iovane, V.; Ghiurmino, G.; Pisanelli, G.; Nava, D.; Baldi, L.; Pagnini, U. Prevalence of antibodies to selected viral and bacterial pathogens in wild boar (Sus scrofa) in Campania region, Italy. J. Wildl. Dis. 2010, 46, 316-319. [CrossRef]

54. Bergagna, S.; Zoppl, S.; Ferrogllo, E.; Gobetto, M.; Dondo, A.; Di Glannatale, E.; Gennero, M.S.; Grattarola, C. Epidemiologic survey for Brucella suis biovar 2 in a wild boar (Sus scrofa) population in Northwest Italy. J. Wildl. Dis. 2009, 45, $1178-1181$. [CrossRef]

55. Malmsten, A.; Magnusson, U.; Ruiz-Fons, F.; González-Barrio, D.; Dalin, A.-M. A serologic survey of pathognes in wild boar (Sus scrofa) in Sweden. J. Wildl. Dis. 2018, 54, 229-237. [CrossRef] [PubMed]

56. Cvetnić, Ž.; Špičić, S.; Tončić, J.; Majnarić, D.; Benić, M.; Albert, D.; Thiébaud, M.; Garin-Bastuji, B. Brucella suis infection in domestic pigs and wild boar in Croatia. Rev. Sci. Tech. Off. Int. Epiz 2009, 28, 1057-1067. [CrossRef] [PubMed]

57. Vicente, J.; León-Vizcaíno, L.; Gortázar, C.; Cubero, M.J.; González, M.; Martín-Atance, P. Antibodies to selected viral and bacterial pathogens in European wild boars from southcentral Spain. J. Wildl. Dis. 2002, 38, 649-652. [CrossRef]

58. Melzer, F.; Lohse, R.; Nieper, H.; Liebert, M.; Sachse, K. A serological study on brucellosis in wild boars in Germany. Eur. J. Wildl. Res. 2007, 53, 153-157. [CrossRef]

59. Hubálek, Z.; Treml, F.; Juřicová, Z.; Huňady, M.; Halouzka, J.; Janík, V.; Bill, D. Serological survey of the wild boar (Sus scrofa) for tularaemia and brucellosis in South Moravia, Czech Republic. Vet. Med. (Praha). 2002, 47, 60-66. [CrossRef]

60. Leuenberger, R.; Boujon, P.; Thür, B.; Miserez, R.; Garin-Bastuji, B.; Rüfenacht, J.; Stärk, K.D.C. Prevalence of classical swine fever, Aujeszky's disease and brucellosis in a population of wild boar in Switzerland. Vet. Rec. 2007, 160, 362-368. [CrossRef] [PubMed]

61. Pedersen, K.; Quance, C.R.; Robbe-Austerman, S.; Piaggio, A.J.; Bevins, S.N.; Goldstein, S.M.; Gaston, W.D.; DeLiberto, T.J. Identification of Brucella suis from feral swine in selected states in the usa. J. Wildl. Dis. 2014, 50, 171-179. [CrossRef]

62. Roop, R.M.; Barton, I.S.; Hopersberger, D.; Martin, D.W. Uncovering the Hidden Credentials of Brucella Virulence. Microbiol. Mol. Biol. Rev. 2021, 85. [CrossRef]

63. Manterola, L.; Tejero-Garcés, A.; Ficapal, A.; Shopayeva, G.; Blasco, J.M.; Marin, C.M.; López-Goñi, I. Evaluation of a PCR test for the diagnosis of Brucella ovis infection in semen samples from rams. Vet. Microbiol. 2003, 92, 65-72. [CrossRef]

64. Lambert, S.; Gilot-Fromont, E.; Freycon, P.; Thébault, A.; Game, Y.; Toïgo, C.; Petit, E.; Barthe, M.N.; Reynaud, G.; Jaÿ, M.; et al. High shedding potential and significant individual heterogeneity in naturally-infected Alpine ibex (Capra ibex) with Brucella melitensis. Front. Microbiol. 2018, 9, 1065. [CrossRef]

65. Uhrig, S.R.; Nol, P.; McCollum, M.; Salman, M.; Rhyan, J.C. Evaluation of transmission of Brucella abortus strain 19 in bison by intravaginal, intrauterine, and intraconjunctival inoculation. J. Wildl. Dis. 2013, 49, 522-526. [CrossRef]

66. Ridler, A.L.; Smith, S.L.; West, D.M. Seroconversion and semen shedding in rams experimentally infected with Brucella ovis. N. Z. Vet. J. 2014, 62, 47-50. [CrossRef]

67. Letesson, J.J.; Barbier, T.; Zúñiga-Ripa, A.; Godfroid, J.; De Bolle, X.; Moriyón, I. Brucella genital tropism: What's on the menu. Front. Microbiol. 2017, 8, 506. [CrossRef] 
68. Queipo-Ortuño, M.I.; Colmenero, J.D.; Muñoz, N.; Baeza, G.; Clavijo, E.; Morata, P. Rapid Diagnosis of Brucella epididymo-orchitis by Real-Time Polymerase Chain Reaction assay in urine samples. J. Urol. 2006, 176, 2290-2293. [CrossRef]

69. Anderson, T.D.; Meador, V.P.; Cheville, N.F. Pathogenesis of placentitis in the goat inoculated with Brucella abortus. I. Gross and Histologic Lesions. Vet. Pathol. 1986, 23, 219-226. [CrossRef] [PubMed]

70. Papatsoris, A.G.; Mpadra, F.A.; Karamouzis, M.V.; Frangides, C.Y. Endemic brucellar epididymo-orchitis: A 10-year experience. Int. J. Infect. Dis. 2002, 6, 309-313. [CrossRef]

71. Ridler, A.L.; West, D.M. Control of Brucella ovis infection in sheep. Vet. Clin. N. Am. Food Anim. Pract. 2011, 27, 61-66. [CrossRef]

72. Smith, H.; Williams, A.E.; Pearce, J.H.; Keppie, J.; Harris-Smith, P.W.; Fitz-George, R.B.; Witt, K. Fœetal erythritol: A cause of the localization of Brucella abortus in bovine contagious abortion. Nature 1962, 193, 47-49. [CrossRef]

73. Clark, J.B.; Graham, E.F.; Lewis, B.A.; Smith, F. D-mannitol, erythritol and glycerol in bovine semen. J. Reprod. Fertil. 1967, 13, 189-197. [CrossRef]

74. Essenberg, R.C.; Seshadri, R.; Nelson, K.; Paulsen, I. Sugar metabolism by Brucellae. Vet. Microbiol. 2002, 90, 249-261. [CrossRef]

75. Pruneda, A.; Pinart, E.; Bonet, S.; Yeung, C.H.; Cooper, T.G. Study of the polyol pathway in the porcine epididymis. Mol. Reprod. Dev. 2006, 73, 859-865. [CrossRef]

76. Lowrie, D.B.; Kennedy, J.F. Erythritol and threitol in canine placenta: Possible implication in canine brucellosis. FEBS Lett. 1972, 23, 69-72. [CrossRef]

77. Burkhardt, S.; Jiménez De Bagüés, M.P.; Liautard, J.P.; Köhler, S. Analysis of the behavior of eryC mutants of Brucella suis attenuated in macrophages. Infect. Immun. 2005, 73, 6782-6790. [CrossRef]

78. Jauniaux, E.; Hempstock, J.; Teng, C.; Battaglia, F.C.; Burton, G.J. Polyol concentrations in the fluid compartments of the human conceptus during the first trimester of pregnancy: Maintenance of redox potential in a low oxygen environment. J. Clin. Endocrinol. Metab. 2005, 90, 1171-1175. [CrossRef]

79. De Massis, F.; Zilli, K.; Di Donato, G.; Nuvoloni, R.; Pelini, S.; Sacchini, L.; D'Alterio, N.; Giannatale, E. Di distribution of Brucella field strains isolated from livestock, wildlife populations, and humans in Italy from 2007 to 2015. PLoS ONE 2019, 14, e0213689. [CrossRef] [PubMed]

80. Bertelloni, F.; Forzan, M.; Turchi, B.; Sagona, S.; Mazzei, M.; Felicioli, A.; Fratini, F.; Cerri, D. A serological survey on swine brucellosis using standard procedures, Dot Blot, and Western Blot in finisher pigs in Central-North Italy. Vet. Sci. $2018,5,86$. [CrossRef] 